\title{
Olağanüstü Olayların Sosyal Yaşam ve Kültürlere Etkisi; Covid-19 Salgınının Türk Kültürüne Etkisi Üzerine Bir Araştırma*
}

\section{The Effect of Extraordinary Events on Social Life and Cultures; An Investigation on The Effect of Covid-19 Outbreak on Turkish Culture}

\author{
Mustafa İnce, ${ }^{a}$ Mesut Yilmaz ${ }^{b}$ \\ ${ }^{a}$ Doç. Dr., Karabük Üniversitesi, Karabük, Türkiye. \\ mince7@hotmail.com \\ ORCID: 0000-0001-8058-1076 \\ b Arş. Gör., Karabük Üniversitesi, Karabük, Türkiye. \\ mesutyilmaz@karabuk.edu.tr \\ ORCID: 0000- 0003-0053-5147
}

\section{MAKALE BİLGISİ}

\section{Makale Geçmişi:}

Başvuru tarihi: 17.09.2020

Düzeltme tarihi: 30.11 .2020

Kabul tarihi: 21.12.2020

Anahtar Kelimeler:

Covid-19

Pandemi,

Sosyal Yaşam,

Korona virüs,

Kültür,

\section{ÖZ}

Covid-19 virüsü bütün dünyada eşi benzeri görülmemiş bir kaosa sebep olmuş, başta gündelik hayat ve sosyal yaşam olmak üzere üretimi, tüketimi, ticareti, eğitimi, örgütleri, uluslararası ilişkileri, kamusal yapıyı derinden etkileyerek bir anda dünyanın adeta gidişatını değiştirmiştir. Öyle ki, tıp dünyasında Covid-19 olarak adlandırılan bu salgının, son 50 yılın en büyük sosyal ve ekonomik krizine neden olduğu belirtilmektedir. Henüz tam ve onaylanmış spesifik bir tedavisi ve aşısı olmayan bu hastalığın oluşturduğu endişe ve panik bir yana, bireylerde ve toplumlarda uzun vadede farklı konularda bırakacağı kalıcı tesirlerin boyutu giderek daha fazla ön plâna çıkmaktadır. $\mathrm{Bu}$ salgının dünya genelinde, toplumlarda, yakın gelecekte iktisadi, sosyal ve kültürel açıdan önemli değişikliklere sebep olabileceği, toplumsal ilişkileri farklı boyuta taşıyabileceği değerlendiril-mektedir. Türkiye'de de salgının yayılmasını durdurmak ve olumsuz etkilerini en aza indirmek adına birçok alanda kısıtlayıcı uygulamalar ve çeşitli tedbirler hayata geçirilmiştir. Bunlardan bazıları kriz dönemiyle sınırlı kalacak olsa da bir kısmının alışkanlığa dönüşeceği düşünülmektedir. Bu çalışmanın amacı, Covid-19 salgınının Türkiye'de sosyal yaşam ve Türk kültürü üzerine olası etkilerini ortaya koymaya çalışmaktır. Çalışmada kullanılan veriler, Türkiye genelinde farklı yaş gruplarında 516 kişiye anket uygulanarak elde edilmiştir. Çalışmadan elde edilen temel bulguya göre, katılımcıların büyük çoğunluğu salgın sürecinde uymak zorunda kaldıkları pek çok (tedbir ve) uygulamaya bundan sonraki yaşamlarında da devam edeceklerini belirtmişlerdir.

\section{ABSTRACT}

Covid-19 virus has caused unprecedented dirt chaos all over the world, and it has changed the course of the world by affecting production, consumption, trade, education, organizations, international relations and public structure, especially daily life and social life. It is stated that this epidemic, which the medical world calls Covid-19, has caused the biggest social and economic crisis of the last 50 years. Aside from the anxiety and panic caused by this disease, which does not have a complete and approved specific treatment and vaccine yet, the extent of permanent effects that it will leave in different subjects in individuals and societies in the long term becomes more and more prominent. It is considered that this epidemic may cause significant changes in the longterm economic, social and cultural aspects of the societies in the world and can bring social relations to a different dimension. To stop the spread of the epidemic in Turkey and the restrictive practices in many areas in order to minimize the negative effects and various measures have been implemented. Although some of these will be limited to the crisis period, some are thought to turn into habit. The aim of this study was to try to reveal Covidien-19 outbreak of the likely impact on social life in Turkey and Turkish culture. The data used in the study, surveyed 516 people in Turkey were obtained by applying across different age groups. According to the main finding obtained from the study, the vast majority of the participants stated that they would continue with many practices they had to follow during the epidemic period. 


\section{Atıf Bilgisi / Reference Information}

İnce, M. ve Yılmaz, M. (2020). Olağanüstü Olayların Sosyal Yaşam ve Kültürlere Etkisi; Covid-19 Salgınının Türk Kültürüne Etkisi Üzerine Bir Araştırma. Uluslararası Kültürel ve Sosyal Araştırmalar Dergisi (UKSAD), 6 (2), Kış, s. 552-571.

\section{Giriş}

“İbn-i Sina'nın insandan insana bulaşan salgın hastalıklara karşı çözüm önerileri; Sirke ile temizlik yapın. Ellerinizi, bulaşıklarınızı ve kıyafetlerinizi mutlaka sirke ile yıkayın. Birlikte dolaşmayın. Beş on kişi bir araya gelerek kalabalıklar oluşturmayın. Pazarları terk edin. Paraları bırakın. Toplu halde ibadet etmeyin. Salgından korkmayın, hastalıktan sakının, hastalarınızı terk etmeyin. Evinizde oturun ve Neşeli olun. Hastalık neşeden kaçar" (TÜBA, 2020:6). İbn-i Sina'nın asırlar öncesinde nasıl korunmamız gerektiğine yönelik -bugün dahi geçerliliğini koruyan- tavsiyelerde bulunduğu büyük salgınlardan biri de bizim yaşadığımız döneme denk gelmiştir.

İlk kez Çin'de ortaya çıkan ve bugün itibariyle dünya genelinde hemen hemen tüm ülkelerde görülen, yeni koronavirüs (SARS-CoV-2), ölümcül bir salgına (COVID-19) neden oldu. Salgın kısa sürede dünyanın büyük bir kesiminde, başta sağlık olmak üzere, gündelik yaşamı, ekonomiyi ve refahı tehdit eden bir pandemiye dönüştü (Yavuz, 2020:182).

"Salgının ortaya çıkardığı sağlık problemlerinin yanı sıra yol açtığı endişe ve korku, toplumları, hastalığın yayılımını engellemeye yönelik modern zamanların en katı tedbirlerini almaya itti. (Congar, 2020). Bazı ülkelerde tamamen, bazı ülkelerde ise kısmen sokağa çıkma yasakları ilan edildi. Karantina gibi virüsün bulaşmasını kontrol altına almak için uygulanan kısıtlamalar nedeniyle insanlar işlerini kaybetti ve geçim kaynakları tehlikeye düştü. Salgından etkilenen pek çok ülkede okullar kapandı, insanlar toplu dini ritüeller, dügünler ve cenazeler gibi önemli kültürel ve toplumsal etkinlikler için bir araya gelemez hale geldi (BM Bildirisi, 06.04.2020). İbadethaneler kapatıld1, konser, eğlence, parti, düğün, cenaze gibi günlük yaşamın parçası olan tören, etkinlik ve organizasyonlar yasaklandı. İnsanlar hiç alışık olmadıkları bir şekilde izolasyona tabi tutulmaya, birbirlerine karşı mesafeli durmaya başladılar. Tüm dünyada yayılmaya devam eden ve inişli çıkışlı bir seyir izleyen salgının dünya nüfusunun yarısından fazlasını enfekte edecek potansiyele sahip olduğu belirtilmektedir. Salgının aynı zamanda ülkelerin ekonomileri üzerinde de ciddi tahribatlara yol açtığ 1 değerlendirilmekte, "Birleşmiş Milletler Ticaret ve Kalkınma Konferansı (UNCTAD) pandemik influenzanın sadece 2020 yılında küresel ekonomiye maliyetinin 2 trilyon doları bulmasını beklediklerini açıklamıştır" (Açıkgöz ve Günay, 2020:521). COVID-19'un toplam maliyetinin ise 5 trilyon doları geçeceği öngörülmektedir.

COVID-19 salgını, insanların sadece gündelik yaşamlarını değil, toplumların sosyoekonomik refah ve huzurunu da doğrudan tehdit etmektedir. Bu durum, yaşanan salgın ile beraber salgının ortaya çıkardığı psikolojik, sosyal, kültürel ve ekonomik etkileri de incelemeyi önemli kılmaktadır. Şimdiye kadar yapılan çalışmalarda çoğunlukla, salgının insan ve toplum sağlı̆ııa olan etkileri, virüsün mikrobiyolojik yapısı, bulaşma yolları, etkilediği insanların bireysel özellikleri vb. gibi krizin tıbbi boyutu ele alınmıştır. "Scopus veri tabanında yapılan araştırmaya göre Nisan 2020 tarihine kadar COVID-19 ile ilgili yapılan 1516 yayının 1249'u tıp alanında, geri kalanların büyük çoğunluğu ise mikrobiyoloji, farmakoloji, biyoloji, hemşirelik vb. sağlıkla ilgili diğer konulardadır. Salgının sosyal ve ekonomik boyutunu ele alan çalışmaların sayısı ise sınırlıdır" (Yavuz, 2020:183). Covid-19 ile ilgili sosyal bilimler ve ekonomi alanında yayınlanan makale sayısı ise sadece 51'dir. Bu bağlamda salgının sadece tıbbi boyutuyla değil her açıdan toplumda meydana getirdiği/getireceği tahribatların ele alınması büyük önem arz etmektedir.

Dünyayı derinden sarsan Covid-19 virüsünün ilk başta sadece tıbbi yönleri merkeze alınmış olsa da salgının -tıbbi- etkisi azaldıkça sosyal boyutunun tahribatı ortaya çıkmaya başlamış, ülkeler de süreçle ilgili psikolojik, sosyal, kültürel, ekonomik vb. konulardaki hasarları öncelemiş, bu alanlardaki hasar tespit çalışmalarına hız verilmiştir. Aslında bu salgın, tıbbı açıdan ele alındığında, er ya da geç ilaçlarla kesin olarak tedavi edilebilecek veya aşıyla kontrol altına alınabilecektir. Hatta bir şekilde kendiliğinden - 
mutasyona uğramas1- yok olması da mümkündür. Ancak, uzun vadede bireyler ve toplumlar üzerinde ciddi kalıcı bazı olumsuz etkiler bırakabileceği kaçınılmaz gibi gözükmektedir.

Koronavirüsle mücadelede ülkeler farklı yöntem ve teknikler uygulamışlardır. "Toplum sağlı̆̆ının korunmasını esas alan bu mücadele süreci, bireyi sosyolojik ve psikolojik dönüşümlere uğratarak, eski kazanımlarını ve alışkanlıklarını değiştirerek; üretimden tüketime, eğitimden ticarete, siyasetten felsefeye, kanunlardan yönetim anlayışına hayatın farklı katmanlarını sorgulatan ve anlamlılığını değiştiren yeni bir yönlendirici işlevi görmektedir" (TÜBA, 2020:11).

Salgının yayılmasını önlemek maksadıyla alınan çeşitli kararlar, hayata geçirilen bazı uygulamalar, bireysel önlemler çerçevesinde alınan kimi tavsiye kararları, 'yeni normal' ekseninde sosyal yaşamda farklılaşmaya zemin oluşturacaktır. Bütün bunların toplumsal yaşamda, üretimde, ticarette, eğitimde ve sosyal ilişkilerde belli değişiklikleri beraberinde getirmesi ise kaçınılmazdır. Çoğu kez ihtiyaçların yeni arayışlara sebep olduğu, ortaya çıkacak yeni araştırmaların ise yeni icatlara yol açması da ihtimal dâhilindedir. $\mathrm{Bu}$ çerçevede, daha önce var olan ama yaygın biçimde kullanılmayan bazı araç ve teknolojilerin giderek daha çok kabul görmesinin yanında yepyeni teknolojilerin hayatımıza girmesi de beklenmelidir.

Dolayısıyla, salgınla birlikte toplumsal yaşamda, sosyal ilişkilerde, iş ve işleyiş süreçlerinde, teknolojide bazı değişimlerin yaşanması ve halihazırda bilinen/kullanılan bazı teknolojilerin de eskiye nazaran çok yaygın biçimde kullanılması şaşırtıcı olmayacaktır. Başka bir deyişle koronavirüs salgınının kültürler üzerinde derin izler bırakacağı tahmin edilmektedir. Bunların neler olabileceğinin bilinmesi ise alınacak önlemler ve uygulanabilecek bazı tedbirler açısından önemlidir.

\section{Külttür Kavramı}

Salgın hastalık/hastalıklar özelinde, olağanüstü olayların kültürler üzerindeki etkisi anlayabilmek ve değerlendirme yapabilmek için öncelikle kültür kavramının tanımlanması ve açıklanması yararlı olacaktır. Türk Dil Kurumu'na göre Kültür; "Tarihsel, toplumsal gelişme süreci içinde yaratılan bütün maddi ve manevi değerler ile bunlarl yaratmada, sonraki nesillere iletmede kullanılan, insanın doğal ve toplumsal çevresine egemenliğinin ölçüsünü gösteren araçların bütünü, hars, ekin" olarak tanımlanmaktadır. Kültür aslında, çok çeşitli ve çok fazla tanımı olan geniş bir kavramdır. Öyle ki; Raymond Williams'a göre Kültür, İngiliz dilinin en karmaşık iki ya da üç kelimesinden biridir. Kroeber ve Kluckhohn da kültürün 164 farklı tanımını bulmuşlardır. 'Kültür' terimi, yaygın olarak kültivasyon ile aynı kökten gelen ve tarımla ilişkili kullanılan genel bir kavramdır (Eldes, 2006:6). Yine İngilizce 'deki ilk kullanımlarında din ve tapınma ile ilişkili 'cult' kelimesiyle bağlantılı olarak, hayvanların ve ekinlerin yetiştirilmesi (cultivation) şeklinde kullanımı da mevcuttur (Smith, 2007:13).

“Kültür sözcüğü Latince kökenlidir ve Türkçeye Fransızcadan gelmiştir. Latincede 'cultura' sözcüğü 'toprağı ekip biçme' ve 'hayvan yetiştirme' anlamına gelmekteydi. 17. Yüzyılın sonuna doğru halkın 'bütün bir yaşama biçimi' şeklinde Almanca ve İngilizceden batı dillerine girmiştir. 18. Yüzyıla gelindiğinde ise antropolojideki gelişmeler sonucu 'bütünsel bir yaşam şekli' anlamını kazanmıştır. Voltaire, Fransız ihtilali öncesinde kültür sözcügüne 'insan zekasının oluşumunu ve gelişimini belirleyen' bir terim olarak yeni bir anlam kazandırmıştır” (b.t., 2020:3).

Kültürün birçok tanımı olmasına rağmen yaygın olarak kullanılan tanımını Kroeber ve Kluckhohn (1952) şu şekilde yapmaktadır; "İnsan gruplarının özgün yapılarını ortaya koyan, yaratılan ve aktarılan sembollerle ifade edilen düşünce, duygu ve davranış biçimleridir. Kültürün temelini geleneksel görüşler (tarihsel süreçte oluşmuş ve seçilmiş) ve özellikle onlara atfedilen değerler oluşturmaktadır; kültürel sistemler bir yandan davranışın ürünü, diğer yandan gelecekteki davranışın koşullayıcısıdır.”

Genel olarak kültürün özelliklerini; Öğrenilebilir olması, göreli olması, bütünleştirici olması, toplum üyelerince paylaşılır olması, aktarılabilir olması, belli kurallarının olması, ihtiyaçları giderebilir olması, değişebilir olması, toplumun değerlerini bir bütün haline getirmesi ve bunları sistematik bir biçimde taşıması, vb. şeklinde sıralamak mümkündür. 
Ayrıca, Boyle ve Andrews'e göre kültürün dört temel özelliği bulunmaktadır (Akt: Bolsoy ve Sevil, 2010: $81)$

- Kültür öğrenilir ve kuşaktan kuşağa aktarılır. İnsanlar kendi öz kültürlerini doğuştan itibaren öğrenmeye başlarlar.

- Kültür "paylaşılır".

- Kültür bireyin çevresine "uyumudur".

- Kültür "dinamik" ve "değişen” bir süreçtir.

Kültür olgusu, değişiklik göstermeyen, her zaman aynı kalan bir anlamlar bütünü değildir; sosyal ve ekonomik yapıya, zamana ve siyasal olaylara bağlı olarak değişikliğe uğrayabilir; başka kültürlerle karşılıklı bir şekilde alışverişte bulunabilmektedir. Kültür değişmelerinde 'sağlıklı' olan yol, dayatmacı olmadan, temel kalıp korunarak çağın ihtiyaçlarına göre kendiliğinden yeni şekil alması, diğer bir ifadeyle gelişerek değişim süreci izlemesidir (Mahiroğulları, 2010: 1279). Kültür değişimlerinde sözü geçen bu 'sağlıklı' yolun en sağlıklısı kelime anlamını da tam olarak karşılayabilecek şekilde bir dönüşüm en çok salgın dönemlerinde meydana gelebilmektedir. Tarihsel süreçte toplum sağlığını tehdit eden küresel bir salgın ortaya çıktığında, bu salgından korunma yöntemlerinde her zaman "kişisel temizlik" ön plâna çıkartılarak 'sağlıklı' kalmanın yollarına değinilmiştir.

Her toplumun kendine özgü kültürü ve kültürel değerleri vardır. Bu kültürel öğeler aynı zamanda o toplumun yaşama biçimidir. Kültürlerin birbirlerine üstünlügü söz konusu değildir, ancak bazı kültürler baskın kültür olarak öne çıkabilmektedir. Kültürlerin oluşumunda dil, din-inanç, düşünce yapıs1, hukuk kuralları, ahlak kuralları, gelenek görenek, siyasal örgütlenme gibi manevi (soyut) unsurların yanı sıra, iklim, coğrafi konum, doğal kaynaklar, simgesel değerler gibi maddi (somut) unsurlar da etkilidir. Her toplumun kültürel yapısı birbirinden farklı olsa da toplumlar ve kültürler birbirlerinden etkilenirler.

\section{Olağanüstü Olayların Toplumlar Üzerindeki Etkisi}

Kültür yaşayan bir olgudur, dolayısıyla bu durum kültürün gelişebileceğini, değişebileceğini ve kısmen ya da tamamen ortadan kalkabileceğini gösterir. Yaşadığımız çağla birlikte, kendi toplumumuzun da sürekli bir değişim ve dönüşüm içinde olması bazı kültürel sorunları da beraberinde getirmektedir. Teknolojik gelişmeler, ekonomik olaylar, kaoslar, krizler, dış güçlerin baskısı, tehdit ve tahrikler, çevresel faktörlere bağlı olarak ortaya çıkan bazı yeni yaşam biçimleri, teknolojinin nimetlerinden sorumsuzca yararlanma tutkusu, daha fazla konforlu yaşama arzusu gibi sebeplerden ötürü değişen değer yargıları, kültürleri baskılamakta ve değişime zorlamaktadır.

Kültürün süreç içerisinde değişime uğramasına neden olan pek çok olaydan-sebepten bahsetmek mümkündür. Bu olayların kimisi insan eliyle gerçekleşirken kimisi ise doğal -veya kendiliğinden gelişenolaylar sonucu ortaya çıkmaktadır. Kültürel dönüşüme etki eden faktörler temel olarak şunlardır (Bulut, 2020:12):

1. Kültürlerle dostane ilişkiler çerçevesinde etkileşim,

2. Toplumsal ilişkilerdeki dönüşüm,

3. Politik yapıdaki dönüşüm,

4. Teknolojik gelişmeler,

5. Savaşlar,

6. İşgaller,

7. Doğal afetler vb.

8. Salgin hastalıklar vb. 
Bu olayların kültürler üzerindeki etkisi kısa süreli olabileceği gibi kalıcı da olabilir. Hatta kimi olaylar bazı kültürel öğeleri tamamen ortadan kaldırabilir.

Bugün karşı karşıya kaldığımız salgın da toplumların geçmişten gelen bazı tutum ve davranışlarını değiştirmiş, sınırlandırmış ya da tamamen ortadan kalkmasına zemin hazırlamıştır. Üstelik bu değişim sosyal yaşamdan aile ilişkilerine, üretimden ticarete, eğitimden mimariye, beslenmeden kişisel bakıma hemen hemen her alanda kendini göstermiştir. "Halihazırda salgın nedeniyle maruz kaldığımız sınırlamaların ve iş yapma biçimlerimizdeki değişikliklerin bir kısmının kalıcı hale gelebileceğini söyleyen Reeves ve arkadaşları, tarihte bu tür toplumsal krizlerin insanlığın tutum ve davranışlarını yeniden şekillendirebildiğine yönelik önemli örnekler bulunduğuna dikkat çekmektedir" (Escarus, 2020:12)

Aslında Covid-19 salgını bugüne kadarki son önemli salgın olma özelliğine sahip ama, dünya daha önce de benzer salgınlarla karşı karşıya kalmıştır. Üstelik bu salgınlarda milyonlarca kişi hayatını kaybetmiştir. Örneğin, 1918'de başlayan 'İspanyol Gribi Salgını' nda 50 milyon, 'Kara Ölüm' olarak da bilinen 14. yüzyıldaki veba salgınında ise 200 milyona yakın insanın öldügü tahmin edilmektedir. Nesiller önce yaşanmış olayların bireylerin psikolojisini etkilemesi gerçekçi olmasa da tarih boyunca yaşanmış salgınların toplumsal yapıları ve kültürleri derinden etkilemiş olabileceğini gösteren birçok bilimsel bulguya sahip durumdayı.

Yakın dönemde, SARS 2003, Influenza A H1N5 -kuş gribi- 2007, İnfluenza A H1N1 -domuz gribi- 2009, MERS 2012, Influenza A H7N9 2013, Ebola 2014, Zika 2015 salgınları da ülkeler ve toplumlar üzerinde ciddi tesirler bırakmıştır. "Salgınlar dünya tarihinde yönetim ve yaşam değişikliklerine yol açan ve global etkileri olan önemli sağlık olaylarıdır. En büyük çapta yaşanan örnekleriyle bu etkileri görmek mümkün olmuştur. Tarihteki salgınlar, beslenmeden mimariye, üretimden alışverişe, yönetimden davranışa ve hatta imparatorlukların yıkımına kadar birçok konuda yeni gelişmelerin nedeni olarak kabul edilmiştir. Örneğin; Avrupa, Avrasya ve Kuzey Amerika kitalarında tam rakam bilinmemekle birlikte 1300'lerde milyonlarca kişi, Italya'da yaşanan Kara Veba (Black Death) yüzünden ise 75-125 milyon kişi hayatını kaybetmiştir. Bu salgın, sonuçları ve etkileriyle, Avrupa'nın en büyük salgını olarak kabul edilmektedir. Salgın, sosyal, ekonomik ve siyasal etkileri sebebiyle Avrupa'da feodalizmin çökmesinde temel etken olarak değerlendirilmektedir"” (TÜBA, 2020:22).

Tablo 1: Toplumsal değişime neden olan bazı olaylar.

\begin{tabular}{|l|l|}
\hline Kara Veba Salgııı & $:$ Feodalizm ve Serfliğin sona ermesi \\
\hline II. Dünya Savaşı & $:$ Kadınların iş gücüne dahil olması \\
\hline Sars Salgııı & $:$ Online alışverişin artması \\
\hline 11 Eylül Saldırısı & $:$ Gözetim Toplumuna (Gönüllü) Geçiş \\
\hline
\end{tabular}

Kaynak: Escarus, 2020:12.

Tarihte 'olağanüstü' olarak değerlendirilen pek çok olay, yeni durumlar ortaya çıkarmış ve bazı yeni başlangıçları da beraberinde getirmiştir. Aslında bu olaylar sebebiyle toplumlar için hiçbir şey eskisi gibi olmamıştır. $\mathrm{Bu}$ makalenin yazıldığı sırada Covid-19 hastalığına yakalanan insan sayısı 29,734,104 olurken bu hastalık nedeniyle hayatını kaybeden insan sayıs1 939,279'dur (www.worldometers.info, 2020). Salgın hâlâ devam etmekte ve vaka, ölüm sayıları artmaktadır. Toplumsal yaşam için büyük bir tehlike olan Covid-19 salgını olağanüstü salgın durumu olarak nitelendirilmekte ve bu salgının sosyal ve ekonomik yapıya birçok zararı bulunmaktadır. 


\section{Araştırma}

\subsection{Covid-19 Salgınının Türk Kültürü Üzerine Etkileri}

Kültür, birlikte yaşama sonucu ortaya çıkan ve aynı zamanda birlikte yaşamanın koşulunu belirleyen bir olgudur. Dolaysısıyla her toplumun zaman içinde benimsediği ve kendine özgü kuralları birbirinden farklılık gösterebilir. Kültür; inanç, ırk ve doğal değişkenlerle etkileşim halinde, insanlığın evrimini irdeleyen bir değişkendir. İnsanlar ve toplumların neden birbirlerine benzedikleri ya da benzemedikleri, niçin ve nasıl değiştikleri gibi insanlığın evrimiyle ilgili soruların cevapları bu araçlardan oluşan kültürel birikimlerde yatar.

"Her kültürün kendi toplumsal normları ve kuralları vardır, toplumsal etkileşim sürecinde bireyler söz konusu normlar ve kurallar çerçevesinde davranırlar. Bir kültürün etkileşim normları ve kuralları, bu kültürün üyelerinin iletişim biçemlerini belirler. Bireyler, sosyalleşme ve kültürlenme sürecinde bu anlayış ve davranış biçemini öğrenirler" (Ünalan, 2018:438). Dolayısıyla birey, kendi kültürüne ilişkin pek çok kodu sorgulamadan, kendiliğinden yapar duruma gelmektedir.

Kendine özgü pek çok farklı özelliğe sahip olan Türk kültürü, başta aile bağları olmak üzere, akrabalık ilişkileri, arkadaşlık ilişkileri, duygusallık, dostluk, yardımseverlik, samimiyet, merhamet, vefa, temizlik vb. özellikleriyle diğer kültürlerden ayrışmaktadır. Özellikle aile ve akrabalık ilişkileri Türk kültüründe ilk göze çarpan özelliklerdendir. "Türk ailesinde saygı, sevgi ve uyum vardır. Ailenin kurucuları olan kadın ve erkek iyi vasıflar taşıyan, birbirlerine karşı ölçülü, saygılı ve anlayışlı davranan kişilerdir. Işste bu aile yapısı, sağlıklı bir toplumunun doğmasına yol açarak toplumu oluşturan kişilerin makul ilişkiler içinde huzurlu ve ahenkli bir hayat sürebilmelerini mümkün kılmıştır. Ailenin kutsallı̆̆ı, aile üyelerini birbirine yaklaştırır. Ana, baba ve evlâtlar arasında sadakat, sevgi ve sayg bağl son derece kuvvetlidir" (Öğ̈̈t-Eker, 2001: 134). Öyle ki aile fertleri normal zamanlarda dahi sürekli irtibat halinde bulunurlar, önemli günlerde ve bilhassa olağanüstü durumlarda mutlaka bir araya gelirler. Beğlan Toğrol, 'Kültür Taşıyıcı Olarak Türk Ailesi; Doğu'dan Batı'dan Örnekler' isimli çalışmasında bu durumu, 'Nerede bulunursa bulunsunlar ailenin bütün fertlerinin irtibat halinde olduğu ve hastalık, ölüm, afet vs. gibi bir kriz anında derhal birleştikleri görülüyordu” ş̧eklinde açıklamaktadır (Toğrol, 2012:53).

Türk kültüründe toplumsal ilişkiler çerçevesinde, kişisel yakın diyalog anlayışı da büyük önem arz etmektedir. Türkler özellikle İslamiyet'i kabul ettikten sonra, Müslümanlığın değerlerini yaşamlarına tatbik etmişlerdir. Selamlaşma, sarılma, tokalaşma gibi münasebetler önemli kültürel öğeler olmuştur. Türkiye Diyanet Vakfi İslam Ansiklopedisinde, tokalaşmanın önemli bir değer olduğu vurgulanmış, İslâm'da Müslüman kardeşliğini güçlendirmek için selâmlaşma, musâfaha (tokalaşma) ve güler yüzlü olmanın teşvik edildiği belirtilmiştir. Yine Türkiye Diyanet Vakfı İslam Ansiklopedisinde, Selâmlaşmanın bir parçası sayılan tokalaşma Hz. Peygamber'in sünnetinde yer alan âdâb-1 muâşeret kaidelerinden biri olarak kabul edilmiştir.

"Türk kültür tarihinde selamlaşma işleviyle kullanılan, beden dili ve davranış biçimleri arasındaki başlıca selamlaşma yöntemlerini el sıkışmak, başın öne doğru ĕgilmesiyle saygı gösterisinde bulunmak, el sallamak, elin baş tarafina götürülmesi, sağ eli göğsün üzerine götürmek, sarllmak, el sıkışarak veya omuzları birleştirerek sarılmak, gülümsemek/göz kırpmak, başı hafifçe öne doğru ĕgmek ve el öpmek şeklinde stralamak mümkündür” (Keskin, 2017:128)

Bunlarla birlikte Türk kültürünü diğer pek çok kültürden ayıran bir başka özellik ise temizliktir. Türklerin başka pek çok konuda olduğu gibi temizlik konusunda Avrupalılardan daha üstün olduğunun kanıtlamaya çalışan İsmâil Hâmî Dânişmend, 'Cesareti ve Ahlakı ile Örnek Millet: Türkler' adlı kitabının temizlik ile ilgili 'Eski Türk temizliği ve kanaatkârlığı ve bunların sağlık açısından önemi' ismindeki bölümünde, “Eski Türk temizliğinin esası, İslam'ın temizliği imandan sayan düsturudur. Bu yüzden tüm Türkler son derece temiz insanlardır. Türklerin temizlikleri umumi helayı ve hamamı kullanmalarına yol açmış, bu sayede hastalıklardan korunmuşlar ve uzun yaşama şansına sahip olmuşlardır. Oysa Avrupalılar yıkanmazlar, sokakları umumi hela durumundadır, bu nedenle çok hastalıklara yakalanır ve çok kısa hayat sürerler..." (Göka, 2012:1) ifadelerini kullanmıştır. Danişmend'in bu tespitleri aslında Batılı 
gözlemcilerin 16.-18. Yüzyılları arasında Osmanlı İmparatorluğu hakkında yazdığı kitaplara dayanmaktadır.

Yukarıda bir kısmına değinmeye çalıştığımız Türk kültürü, kendine has pek çok özelliğe sahip olmakla beraber Covid-19 salgını, Türk toplumunun bu kültürel özellikleri üzerinde olumsuz etki bırakma potansiyeline sahiptir. Öyle ki, bu süreçte hastalığın yayılmasının önlenmesinde hayati öneme sahip birçok uygulama bu kültürel değerlerle çelişmektedir.

\subsection{Araştırmanın Amacı ve Önemi}

$\mathrm{Bu}$ çalışmanın amacı Covid-19 salgınının Türk kültürü üzerindeki olası etkilerini değerlendirmeye çalışmaktır. Covid-19 pandemisi tüm dünyada milyonlarca insanın yaşamını etkilemiş ve etkilemeye devam etmektedir. Üstelik Covid-19'un insanlar üzerindeki etkisi sadece sağlık alanıyla sınırlı olmayıp, salgının psikolojik, sosyolojik, ekonomik vb. pek çok boyutu bulunmaktadır. Salgının tıbbi olarak olumsuz etkilerinin azaltılmasına yönelik dünya genelinde yoğun çalışmalar yapılmakta, tedavi ve aş1 konusunda önemli adımlar atılmaktadır. Ancak virüsün insanlar ve toplumlar üzerinde kısa ve uzun vadede bırakacağı olumsuz etkilerin neler olabileceği ve bu etkilerin azaltılmasına yönelik nelerin yapılabileceği hususu da büyük önem arz etmektedir. Türkiye'de de salgının yayılmasını durdurmak ve olumsuz etkilerini en aza indirmek adına birçok alanda kısıtlayıcı uygulamalar ve çeşitli tedbirler hayata geçirilmiştir. Bunlardan bazıları kriz dönemiyle sınırlı kalacak olsa da bir kısmının alışkanlığa dönüşeceği düşünülmektedir. Bu çalışmanın amacı, Covid-19 salgınının Türkiye'de sosyal yaşam ve Türk kültürü üzerine olası etkilerini ortaya koymaya çalışmaktır.

\subsection{Araștırmanın Yöntemi, Evreni ve Örneklemi}

Çalışmada kullanılan veriler, Türkiye genelinde (20-65 yaş arası) farklı yaş gruplarında 516 kişiye online anket uygulanarak elde edilmiştir. Anketin uygulanması için Karabük Üniversitesi Sosyal ve Beşerî Bilimler Araştırmaları Etik Kurulu'ndan (2020/09-6 sayılı karar ile) onay alınmıştır. Katılımcılara, 29 sorudan ve 3 bölümden oluşan anketin ilk kısmında sosyo- demografik özelliklere yönelik sorular, ikinci kısımda internet kullanımlarına yönelik sorular, üçüncü ve son bölümde ise Covid-19 salgınına yönelik tutum ve davranışlarını ölçmeyi amaçlayan sorular yöneltilmiştir. Anket sonuçlarından elde edilen veriler, SPSS programı yardımıyla işlenerek değerlendirilmeye çalışılmıştır. 25 Haziran-4 Temmuz 2020 tarihleri arasında gerçekleştirilen çalışmanın evrenini Türkiye genelinde (20-65 yaş arasında) farklı yaş gruplarında bulunan 516 kişi oluşturmaktadır. Çalışmanın örneklemi tesadüfi (rassal) örneklem yöntemiyle belirlenen $230(\% 44,6)$ erkek ve $286(\% 55,4)$ kadın olmak üzere 516 kişiden oluşmaktadır.

\subsection{Araştırmanın Temel Soruları}

1. Covid-19 salgını bireysel davranışlarda değişikliklere sebep oldu mu?

2. Covid-19 salgını toplumsal ilişkileri nasıl etkiledi?

3. Covid-19 salgını Türk toplumunun sosyal yaşamında ne tür değişikliklere neden oldu?

4. Covid-19 salgınını toplumsal ilişkiler üzerinde kalıcı etkiler bırakabilir mi? 


\subsection{Bulgular ve Yorum}

Tablo 2. Bağımsız Değişkenlerin Frekans ve Yüzdelik Değer Dağılım Tablosu

\begin{tabular}{|c|c|c|}
\hline Bağımsız Değişken & Bağımsız Değişken Seçeneği & Frekans (f) ve Yüzdelik (\%) Değer \\
\hline \multirow{3}{*}{ Cinsiyet } & Erkek & $230(44,6)$ \\
\hline & Kadın & $286(55,4)$ \\
\hline & Toplam & $516(100)$ \\
\hline \multirow{7}{*}{ Yaş } & 20-24 Yaş & $148(28,7)$ \\
\hline & 25-34 Yaş & $206(39,9)$ \\
\hline & 35-44 Yaş & $105(20,3)$ \\
\hline & 45-54 Yaş & $43(8,3)$ \\
\hline & 55-65 Yaş & $13(2,5)$ \\
\hline & 65 Yaş ve Üzeri & $1(0,2)$ \\
\hline & Toplam & 516 \\
\hline \multirow{3}{*}{ Medeni Durumu } & Evli & $288(55,8)$ \\
\hline & Bekâr & $227(44,0)$ \\
\hline & Toplam & $516(100)$ \\
\hline \multirow{5}{*}{ Eğitim Düzeyi } & İlköğretim & $13(2,5)$ \\
\hline & Lise & $86(16,7)$ \\
\hline & Lisans & $334(64,7)$ \\
\hline & Lisansüstü & $81(15,7)$ \\
\hline & Toplam & $516(100)$ \\
\hline \multirow{8}{*}{$\begin{array}{c}\text { Bir Günde Ortalama İnternet Kullanım } \\
\text { Süresi }\end{array}$} & $10+$ saat & $51(9,9)$ \\
\hline & $8-9$ saat & $52(10,1)$ \\
\hline & 6-7 saat & $80(15,5)$ \\
\hline & 4-5 saat & $155(30,0)$ \\
\hline & $2-3$ saat & $101(19,6)$ \\
\hline & $1-2$ saat & $63(12,2)$ \\
\hline & Daha az & $14(2,7)$ \\
\hline & Toplam & $516(100)$ \\
\hline
\end{tabular}

Tablo 2'de görüldüğü üzere araştırmaya katılanların \%55,4'ü kadınlardan, \%44,6's1 ise erkeklerden oluşmaktadır. Yaş gruplarının dağılımı ise 20-24 yaş aralığında $148(\% 28,7), 25-34$ yaş aralığında 206 (\%39,9), 35-44 yaş aralığında $105(\% 20,3), 45-54$ yaş aralığında $43(\% 8,3)$ 55-65 yaş aralığında da 13 $(\% 2,5)$ kişi şeklindedir. $288(\% 55,8)$ evli ve $227(\% 44,0)$ bekâr olan katılımcıları öğrenim düzeyleri, İlköğretim $13(\% 2,5)$, Lise $86(\% 16,7)$, Lisans $334(\% 64,7)$ Lisansüstü $81(\% 15,7)$ şeklindedir. Araştırmaya katılanların \%9,9'u (51 kişi) 10 + saat ve üstü, \%10,1'i (52 kişi) 8-9 saat, \%15,5'i (80 kişi) 7-7 saat, \%30'u (155 kişi) 4-5 saat, \%19,6’s (101 kişi) 2-3 saat, \%12,2'si (36 kişi) 1-2 saat, \%2,7'si (14 
kişi) ise daha az internet kullandıklarını beyan etmişlerdir. $\mathrm{Bu}$ sonuca göre çalışmaya katılanların $\% 65,5$ 'inin 5 saatten fazla internet kullandıkları anlaşılmaktadır.

\subsection{Anket Katılımcılarına Covid-19 Hakkında Yöneltilen Soru İfadeleri ve Yanıtlarının} Frekans Analizi

Tablo 3. Covid-19 hayata bakışımı tümüyle değiştirdi.

\begin{tabular}{|l|r|r|r|r|}
\hline & \multicolumn{1}{|c|}{ Frekans } & Yüzde & Geçerli yüzde & \multicolumn{1}{c|}{ Kümülatif yüzde } \\
\hline Kesinlikle katılmıyorum & 21 & 4,1 & 4,1 & 4,1 \\
Katılmıyorum & 46 & 8,9 & 8,9 & 13,0 \\
Orta düzeyde katılıyorum & 212 & 41,1 & 41,1 & 51,1 \\
Katılıyorum & 159 & 30,8 & 30,8 & 81,9 \\
Kesinlikle katılıyorum & 78 & 15,1 & 15,1 & 100,0 \\
Total & 516 & 100,0 & 100,0 & \\
\hline
\end{tabular}

Katılımcılar 'Covid-19 hayata bakışımı tümüyle değiştirdi' ifadesine \%87,0 oranında kesinlikle katılıyorum, katılıyorum ve orta düzeyde katılıyorum yanıtlarını vermişlerdir. Buna karşılık katılmıyorum seçeneğini işaretleyenler ise $\% 13,0$ oranındadır.

Tablo 4. Bundan sonra benim için hiçbir şey eskisi gibi olmayacak.

\begin{tabular}{|l|r|r|r|r|}
\hline & \multicolumn{1}{|c|}{ Frekans } & Yüzde & Geçerli yüzde & Kümülatif yüzde \\
\hline Kesinlikle katılmıyorum & 41 & 7,9 & 7,9 & 7,9 \\
Katılmıyorum & 102 & 19,8 & 19,8 & 26,7 \\
Orta düzeyde katıliyorum & 202 & 39,1 & 39,1 & 65,8 \\
Katılıyorum & 123 & 23,8 & 23,8 & 89,6 \\
Kesinlikle katılıyorum & 48 & 9,3 & 9,3 & 100,0 \\
Total & 516 & 100,0 & 100,0 & \\
\hline
\end{tabular}

Katılımcılar 'Bundan sonra benim için hiçbir şey eskisi gibi olmayacak' ifadesine \%72,2 oranında kesinlikle katılıyorum, katılıyorum ve orta düzeyde katılıyorum yanıtlarını vermişlerdir. Buna karşılık kesinlikle katılmıyorum ve katılmıyorum seçenekleri ise \%27,8 oranındadır.

Tablo 5. Covid-19 arkadaşlık ilişkilerimi olumsuz etkiledi.

\begin{tabular}{|l|r|r|r|r|}
\hline & \multicolumn{1}{|c|}{ Frekans } & Yüzde & Geçerli yüzde & Kümülatif yüzde \\
\hline Kesinlikle katılmıyorum & 66 & 12,8 & 12,8 & 12,8 \\
Katılmıyorum & 180 & 34,9 & 34,9 & 47,7 \\
Orta düzeyde katıllyorum & 143 & 27,7 & 27,7 & 75,4 \\
Katılıyorum & 86 & 16,7 & 16,7 & 92,1 \\
Kesinlikle katılıyorum & 41 & 7,9 & 7,9 & 100,0 \\
Total & 516 & 100,0 & 100,0 & \\
\hline
\end{tabular}


Katılımcılar 'Covid-19 arkadaşlık ilişkilerimi olumsuz etkiledi' ifadesine \%52,3 oranında kesinlikle katılıyorum, katılıyorum ve orta düzeyde katılıyorum yanıtlarını vermişlerdir. Buna karşılık kesinlikle katılmıyorum ve katılmıyorum seçenekleri oranı ise \% 47,7 'dir.

Tablo 6. Covid-19 akrabalık ilişkilerimi olumsuz etkiledi.

\begin{tabular}{|l|r|r|r|r|}
\hline & \multicolumn{1}{|c|}{ Frekans } & Yüzde & Geçerli yüzde & Kümülatif yüzde \\
\hline Kesinlikle katılmıorum & 76 & 14,7 & 14,7 & 14,7 \\
Katılmıorum & 208 & 40,3 & 40,3 & 55,0 \\
Orta düzeyde katılıyorum & 124 & 24,0 & 24,0 & 79,0 \\
Katılıyorum & 67 & 13,0 & 13,0 & 92,0 \\
Kesinlikle katılıyorum & 41 & 7,9 & 7,9 & 100,0 \\
Total & 516 & 100,0 & 100,0 & \\
\hline
\end{tabular}

Katılımcılar 'Covid-19 akrabalık ilişkilerimi olumsuz etkiledi' ifadesine \%45,0 oranında kesinlikle katılıyorum, katılıyorum ve orta düzeyde katılıyorum yanıtlarını vermişlerdir. Buna karşılık kesinlikle katılmıyorum ve katılmıyorum seçenekleri ise $\% 55,0$ oranındadır.

Tablo 7. Bundan sonra arkadaşlarımla daha az görüşeceğim.

\begin{tabular}{|l|r|r|r|r|}
\hline & \multicolumn{1}{|c|}{ Frekans } & Yüzde & Geçerli yüzde & \multicolumn{1}{|c|}{ Kümülatif yüzde } \\
\hline Kesinlikle katılmıyorum & 99 & 19,2 & 19,2 & 19,2 \\
Katılmıyorum & 183 & 35,5 & 35,5 & 54,7 \\
Orta düzeyde katılıyorum & 145 & 28,1 & 28,1 & 82,8 \\
Katılıyorum & 65 & 12,6 & 12,6 & 95,4 \\
Kesinlikle katıllyorum & 24 & 4,7 & 4,7 & 100,0 \\
Total & 516 & 100,0 & 100,0 & \\
\hline
\end{tabular}

Katılımcılar 'Bundan sonra arkadaşlarımla daha az görüşeceğim' ifadesine \%45,3 oranında kesinlikle katılıyorum, katılıyorum ve orta düzeyde katılıyorum yanıtlarını vermişlerdir. Buna karşılık kesinlikle katılmıyorum ve katılmıyorum seçenekleri ise $\% 54,7$ oranındadır.

Tablo 8. Bundan sonra akrabalarımla daha az görüşeceğim.

\begin{tabular}{|l|r|r|r|r|}
\hline & \multicolumn{1}{|c|}{ Frekans } & Yüzde & Geçerli yüzde & \multicolumn{1}{|c|}{ Kümülatif yüzde } \\
\hline Kesinlikle katılmıyorum & 74 & 14,3 & 14,3 & 14,3 \\
Katılmıyorum & 176 & 34,1 & 34,1 & 48,4 \\
Orta düzeyde katılıyorum & 137 & 26,6 & 26,6 & 75,0 \\
Katılıyorum & 80 & 15,5 & 15,5 & 90,5 \\
Kesinlikle katıllyorum & 49 & 9,5 & 9,5 & 100,0 \\
Total & 516 & 100,0 & 100,0 & \\
\hline
\end{tabular}

Katılımcılar 'Bundan sonra akrabalarımla daha az görüşeceğim' ifadesine \%51,6 oranında kesinlikle katılıyorum, katılıyorum ve orta düzeyde katılıyorum yanıtlarını vermişlerdir. Buna karşılık kesinlikle katılmıyorum ve katılmıyorum seçenekleri ise $\% 48,4$ oranındadır. 
Tablo 9. Covid-19 sürecinde kendimi çok yalnız hissettim.

\begin{tabular}{|c|c|c|c|c|}
\hline & Frekans & Yüzde & Geçerli yüzde & Kümülatif yüzde \\
\hline Valid & 1 & 2 &, 2 &, 2 \\
\hline Kesinlikle katılmıyorum & 85 & 16,5 & 16,5 & 16,5 \\
\hline Katılmıyorum & 186 & 36,0 & 36,0 & 51,5 \\
\hline Orta düzeyde katılıyorum & 128 & 24,8 & 24,8 & 76.3 \\
\hline Katıliyorum & 76 & 14,7 & 14,7 & 91.0 \\
\hline Kesinlikle katılıyorum & 40 & 8,8 & 8,8 & 100,0 \\
\hline Total & 516 & 100,0 & 100,0 & \\
\hline
\end{tabular}

Katılımcılar 'Covid-19 sürecinde kendimi çok yalnız hissettim' ifadesine \%48,3 oranında kesinlikle katılıyorum, katılıyorum ve orta düzeyde katılıyorum yanıtlarını vermişlerdir. Buna karşılık kesinlikle katılmıyorum ve katılmıyorum seçenekleri ise $\% 51,5$ oranındadır.

Tablo 10. Covid-19 sürecinde beslenme alışkanlıklarım değişti.

\begin{tabular}{|ll|r|r|r|r|}
\hline & \multicolumn{1}{|c|}{ Frekans } & \multicolumn{1}{c|}{ Yüzde } & Geçerli yüzde & \multicolumn{1}{|c|}{ Kümülatif yüzde } \\
\hline Valid & Kesinlikle katılmıyorum & 43 & 8,3 & 8,3 & 8,3 \\
& Katılmıyorum & 134 & 26,0 & 26,0 & 34,3 \\
Orta düzeyde katıllyorum & 103 & 20,0 & 20,0 & 54.3 \\
Katılıyorum & 148 & 28,7 & 28,7 & 83,0 \\
Kesinlikle katılıorum & 88 & 17,0 & 17,0 & 100,0 \\
Total & 516 & 100,0 & 100,0 & \\
\hline
\end{tabular}

Katılımcılar 'Covid-19 sürecinde beslenme alışkanlıklarım değişti' ifadesine \%65,7 oranında kesinlikle katılıyorum, katılıyorum ve orta düzeyde katılıyorum yanıtlarını vermişlerdir. Buna karşılık kesinlikle katılmıyorum ve katılmıyorum seçenekleri ise \%34,3 oranındadır.

Tablo 11. Covid-19 sürecinde uyku-dinlenme alışkanlıklarım değişti.

\begin{tabular}{|l|r|r|r|r|}
\hline & \multicolumn{1}{|c|}{ Frekans } & Yüzde & Geçerli yüzde & Kümülatif yüzde \\
\hline Valid & 4 &, 8 &, 8 &, 8 \\
Kesinlikle katılmıyorum & 47 & 9,1 & 9,1 & 9,1 \\
Katılmıyorum & 103 & 20,0 & 20,0 & 29,1 \\
Orta düzeyde katılıyorum & 88 & 17,1 & 17,1 & 46.2 \\
Katıllyorum & 134 & 26,0 & 26,0 & 72,2 \\
Kesinlikle katıllyorum & 140 & 27.0 & 27.0 & 100,0 \\
Total & 516 & 100,0 & 100,0 & \\
\hline
\end{tabular}

Katılımcılar 'Covid-19 sürecinde uyku-dinlenme alışkanlıklarım değişti' ifadesine \%70,1 oranında kesinlikle katılıyorum, katılıyorum ve orta düzeyde katılıyorum yanıtlarını vermişlerdir. Buna karşılık kesinlikle katılmıyorum ve katılmıyorum seçenekleri ise \%29,1 oranındadır. 
Tablo 12. Covid-19 sürecinde kişisel istek-ihtiyaçlarımı tekrar gözden geçirdim.

\begin{tabular}{|c|c|c|c|c|}
\hline & Frekans & Yüzde & Geçerli yüzde & Kümülatif yüzde \\
\hline Valid & 4 &, 8 & ,8 & 8 \\
\hline Kesinlikle katılmıyorum & 20 & 3,9 & 3,9 & 3,9 \\
\hline Katılmiyorum & 86 & 16,7 & 16,7 & 20,6 \\
\hline Orta düzeyde katılıyorum & 145 & 28,1 & 28,1 & 48.7 \\
\hline Kat1liyorum & 182 & 35,3 & 35,3 & 84,0 \\
\hline Kesinlikle katıliyorum & 79 & 15.2 & 15.2 & 100.0 \\
\hline Total & 516 & 100,0 & 100,0 & \\
\hline
\end{tabular}

Katılımcılar 'Covid-19 sürecinde kişisel istek-ihtiyaçlarımı tekrar gözden geçirdim' ifadesine \%69,6 oranında kesinlikle katılıyorum, katılıyorum ve orta düzeyde katılıyorum yanıtlarını vermişlerdir. Buna karşılık kesinlikle katılmıyorum ve katılmıyorum seçenekleri ise \%29,6 oranındadır.

Tablo 13. Artık insanlarla aramdaki sosyal mesafeye daha fazla dikkat edeceğim.

\begin{tabular}{|c|c|c|c|c|}
\hline & Frekans & Yüzde & Geçerli yüzde & Kümülatif yüzde \\
\hline Valid & 1 & ,2 & ,2 & ,2 \\
\hline Kesinlikle katılmıyorum & 11 & 2,1 & 2,1 & 2,1 \\
\hline Katılmiyorum & 26 & 5,0 & 5,0 & 7,1 \\
\hline Orta düzeyde katılıyorum & 91 & 17,6 & 17,6 & 24,7 \\
\hline Katıliyorum & 212 & 41,1 & 41,1 & 65,8 \\
\hline Kesinlikle kat1liyorum & 175 & 34.0 & 34,0 & 100,0 \\
\hline Total & 516 & 100,0 & 100,0 & \\
\hline
\end{tabular}

Katılımcılar 'Artık insanlarla aramdaki sosyal mesafeye daha fazla dikkat edeceğim' ifadesine \%92,7 oranında kesinlikle katılıyorum, katılıyorum ve orta düzeyde katılıyorum yanıtlarını vermişlerdir. Buna karşılık kesinlikle katılmıyorum ve katılmıyorum seçenekleri ise \% 7,1 oranındadır. 
Tablo 14. Sosyal mesafe kuralının bende alışkanlığa dönüşeceğini düşünüyorum.

\begin{tabular}{|ll|r|r|r|r|}
\hline & \multicolumn{1}{|c|}{ Frekans } & Yüzde & Geçerli yüzde & Kümülatif yüzde \\
\hline Valid & 1 &, 2 &, 2 &, 2 \\
& Kesinlikle katılmıyorum & 19 & 3,7 & 3,7 & 3,7 \\
Katılmıyorum & 79 & 15,3 & 15,3 & 19.0 \\
Orta düzeyde katıllyorum & 156 & 30,2 & 30,2 & 49,2 \\
Katıllyorum & 166 & 32,2 & 32,2 & 81,4 \\
Kesinlikle katıllyorum & 95 & 18,4 & 18,4 & 100,0 \\
Total & 516 & 100,0 & 100,0 & \\
\hline
\end{tabular}

Katılımcılar 'Sosyal mesafe kuralının bende alışkanlığa dönüşeceğini düşünüyorum' ifadesine \% $\% 0,8$ oranında kesinlikle katılıyorum, katılıyorum ve orta düzeyde katılıyorum yanıtlarını vermişlerdir. Buna karş1lık kesinlikle katılmıyorum ve katılmıyorum seçenekleri ise \%19,0 oranındadır.

Tablo 15. Bundan sonra mecbur kalmazsam kimseyle tokalaşmayı düşünmüyorum.

\begin{tabular}{|c|c|c|c|c|c|}
\hline & & Frekans & Yüzde & Geçerli yüzde & Kümülatif yüzde \\
\hline \multirow[t]{6}{*}{ Valid } & Kesinlikle katılmıyorum & 27 & $\overline{5,2}$ & $\overline{5,2}$ & $\overline{5,2}$ \\
\hline & Katılmıyorum & 81 & 15,7 & 15,7 & 20,9 \\
\hline & Orta düzeyde katılıyorum & 123 & 23,8 & 23,8 & 44,7 \\
\hline & Katıliyorum & 157 & 30,4 & 30,4 & 81,1 \\
\hline & Kesinlikle katıliyorum & 128 & 24,8 & 24,9 & 100,0 \\
\hline & Total & 516 & 100,0 & 100,0 & \\
\hline
\end{tabular}

Katılımcılar 'Bundan sonra mecbur kalmazsam kimseyle tokalaşmayı düşünmüyorum' ifadesine \% $\% 1,1$ oranında kesinlikle katılıyorum, katılıyorum ve orta düzeyde katılıyorum yanıtlarını vermişlerdir. Buna karşılık kesinlikle katılmıyorum ve katılmıyorum seçenekleri ise \%20,9 oranındadır.

Tablo 16. Bundan sonra kolay kolay kimseye sarılmayı düşünmüyorum.

\begin{tabular}{|c|c|c|c|c|}
\hline & Frekans & Yüzde & Geçerli yüzde & Kümülatif yüzde \\
\hline Valid & 2 &, 4 &, 4 &, 4 \\
\hline Kesinlikle katılmıyorum & 30 & 5,8 & 5,8 & 5,8 \\
\hline Katılmiyorum & 102 & 19,8 & 19,8 & 24,6 \\
\hline Orta düzeyde katılıyorum & 144 & 27,9 & 27,9 & 52.5 \\
\hline Katıliyorum & 141 & 27,3 & 27,3 & 79.8 \\
\hline Kesinlikle katıliyorum & 97 & 19.8 & 19.8 & 100,0 \\
\hline Total & 516 & 100,0 & 100,0 & \\
\hline
\end{tabular}

Katılımcılar 'Bundan sonra kolay kolay kimseyle sarılmayı düşünmüyorum' ifadesine \%76,0 oranında kesinlikle katılıyorum, katılıyorum ve orta düzeyde katılıyorum yanıtlarını vermişlerdir. Buna karşılık kesinlikle katılmıyorum ve katılmıyorum seçenekleri ise $\% 24,6$ oranındadır. 
Tablo 17. Kolonya, dezenfektan, el yıkama vb. benim için artık vazgeçilmez oldu.

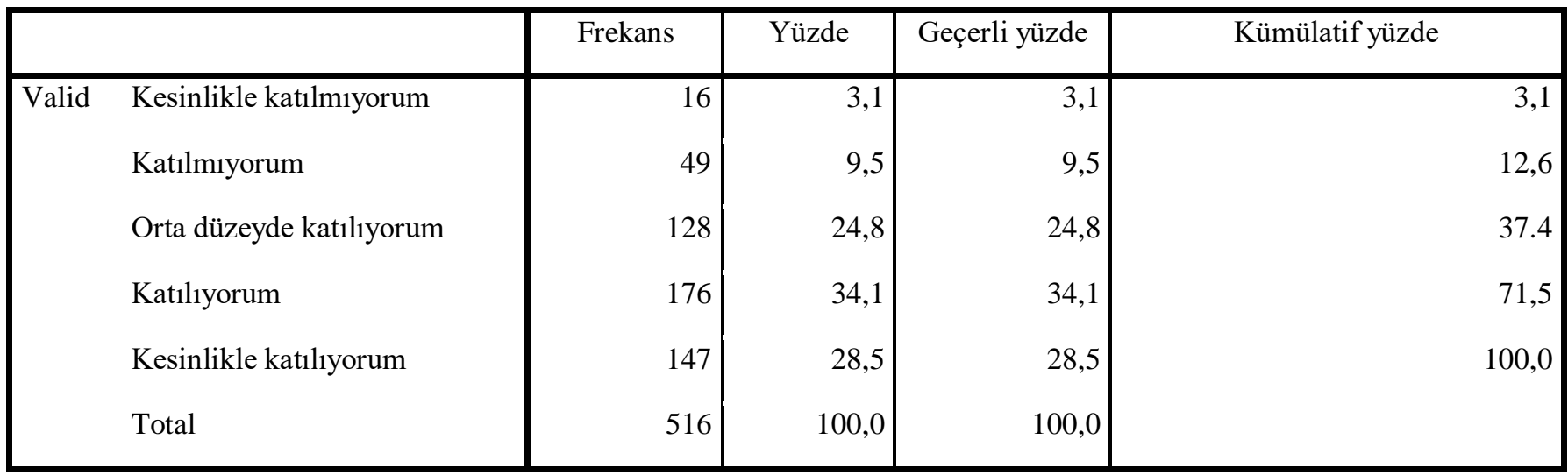

Katılımcılar 'Kolonya, dezenfektan, el yıkama vb. benim için vazgeçilmez oldu' ifadesine \%86,3 oranında kesinlikle katılıyorum, katılıyorum ve orta düzeyde katılıyorum yanıtlarını vermişlerdir. Buna karşılık kesinlikle katılmıyorum ve katılmıyorum seçenekleri ise \%12,6 oranındadır.

Tablo 18. Covid-19 sürecinde şahsi ibadetlerime daha fazla yöneldim.

\begin{tabular}{|l|r|r|r|r|}
\hline & \multicolumn{1}{|c|}{ Frekans } & Yüzde & Geçerli yüzde & Kümülatif yüzde \\
\hline Vald & 1 &, 2 &, 2 &, 2 \\
Kesinlikle katılmıyorum & 55 & 10,7 & 10,7 & 10,7 \\
Katılmiyorum & 136 & 26,4 & 26,4 & 37,1 \\
Orta düzeyde katıllyorum & 158 & 30,6 & 30,6 & 67.7 \\
Katılıyorum & 110 & 21,3 & 21,3 & 89.0 \\
Kesinlikle katıllyorum & 56 & 10,8 & 10,8 & 100,0 \\
Total & 516 & 100,0 & 100,0 & \\
\hline
\end{tabular}

Katılımcılar 'Covid-19 sürecinde şahsi ibadetlerime daha fazla yöneldim' ifadesine \%62,7 oranında kesinlikle katılıyorum, katılıyorum ve orta düzeyde katılıyorum yanıtlarını vermişlerdir. Buna karşılık kesinlikle katılmıyorum ve katılmıyorum seçenekleri ise \%37,1 oranındadır.

Tablo 19. Covid-19 sürecinde hayattan beklentilerimi daha fazla sorguladım.

\begin{tabular}{|c|c|c|c|c|}
\hline & Frekans & Yüzde & Geçerli yüzde & Kümülatif yüzde \\
\hline Valid & 2 &, 4 & 4 & $\overline{4}$ \\
\hline Kesinlikle katılmıyorum & 15 & 2,9 & 2,9 & 2.9 \\
\hline Katılmiyorum & 81 & 15,7 & 15,7 & 18,6 \\
\hline Orta düzeyde katılıyorum & 160 & 31,0 & 31,0 & 49,6 \\
\hline Kat1liyorum & 172 & 33,3 & 33,3 & 82,9 \\
\hline Kesinlikle katıliyorum & 86 & 16.7 & 16.7 & 100,0 \\
\hline Total & 516 & 100,0 & 100,0 & \\
\hline
\end{tabular}

Katılımc1lar 'Covid-19 sürecinde hayattan beklentilerimi daha fazla sorguladım' ifadesine \%81,0 oranında kesinlikle katılıyorum, katılıyorum ve orta düzeyde katılıyorum yanıtlarını vermişlerdir. Buna karşılık kesinlikle katılmıyorum ve katılmıyorum seçenekleri ise $\% 18,6$ oranındadır. 
Tablo 20. Bundan sonra daha az alışveriş yapmayı düşünüyorum.

\begin{tabular}{|c|c|c|c|c|}
\hline & Frekans & Yüzde & Geçerli yüzde & Kümülatif yüzde \\
\hline Valid & 2 &, 4 &, 4 & 4 \\
\hline Kesinlikle katılmıyorum & 45 & 8,7 & 8,7 & 8,7 \\
\hline Katılmıyorum & 167 & 32,4 & 32,4 & 41,1 \\
\hline Orta düzeyde katıliyorum & 156 & 30,2 & 30,2 & 71,3 \\
\hline Katıliyorum & 104 & 20,2 & 20,2 & 91,5 \\
\hline Kesinlikle katıliyorum & 42 & 8,1 & 8,1 & 100,0 \\
\hline Total & 516 & 100,0 & 100,0 & \\
\hline
\end{tabular}

Katılımcılar 'Bundan sonra daha az alışveriș yapmayı düşünüyorum' ifadesine \%58,5 oranında kesinlikle katılıyorum, katılıyorum ve orta düzeyde katılıyorum yanıtlarını vermişlerdir. Buna karşılık kesinlikle katılmıyorum ve katılmıyorum seçenekleri ise $\% 41,1$ oranındadır.

Tablo 21. Aile içi etkileşimimiz (birlikte kaliteli vakit geçirme) olumlu etkilendi.

\begin{tabular}{|c|c|c|c|c|}
\hline & Frekans & Yüzde & Geçerli yüzde & Kümülatif yüzde \\
\hline Valid & 1 & 2 & 2 & ,2 \\
\hline Kesinlikle katılmıyorum & 32 & 6,2 & 6,2 & 6,2 \\
\hline Katılmıyorum & 72 & 14,0 & 14,0 & 20,2 \\
\hline Orta düzeyde katıliyorum & 152 & 29,5 & 29,5 & 49,7 \\
\hline Katıliyorum & 170 & 32,9 & 32,9 & 82,6 \\
\hline Kesinlikle katıliyorum & 89 & 17,0 & 17,0 & 100,0 \\
\hline Total & 516 & 100,0 & 100,0 & \\
\hline
\end{tabular}

Katılımcılar 'Aile içi etkileşimimiz (birlikte kaliteli vakit geçirme) olumlu etkilendi' ifadesine \%79,6 oranında kesinlikle katılıyorum, katılıyorum ve orta düzeyde katılıyorum yanıtlarını vermişlerdir. Buna karşılık kesinlikle katılmıyorum ve katılmıyorum seçenekleri ise \%20,2 oranındadır.

Tablo 22. Covid-19 sürecinde teknolojik cihaz (telefon, bilgisayar vb.) kullanımım arttı.

\begin{tabular}{|c|c|c|c|c|}
\hline & Frekans & Yüzde & Geçerli yüzde & Kümülatif yüzde \\
\hline Valid & 2 &, 4 & ,4 & 4 \\
\hline Kesinlikle katılmıorum & 10 & 1,9 & 1,9 & 1,9 \\
\hline Katılmiyorum & 33 & 6,4 & 6,4 & 8.3 \\
\hline Orta düzeyde katılıyorum & 74 & 14,3 & 14,3 & 22,6 \\
\hline Katılıyorum & 194 & 37,6 & 37,6 & 60,2 \\
\hline Kesinlikle katıliyorum & 203 & 39,4 & 39,4 & 100,0 \\
\hline Total & 516 & 100,0 & 100,0 & \\
\hline
\end{tabular}


Katılımcılar 'Covid-19 sürecinde teknolojik cihaz (telefon, bilgisayar vb.) kullanımım arttı' ifadesine \%91,3 oranında kesinlikle katılıyorum, katılıyorum ve orta düzeyde katılıyorum yanıtlarını vermişlerdir. Buna karşılık kesinlikle katılmıyorum ve katılmıyorum seçenekleri ise \%8,3 oranındadır.

Tablo 23. Artık insanlarla daha çok telefon ve internet üzerinden görüşeceğim.

\begin{tabular}{|c|c|c|c|c|}
\hline & Frekans & Yüzde & Geçerli yüzde & Kümülatif yüzde \\
\hline Valid & 2 &, 4 &, 4 & ,4 \\
\hline Kesinlikle katılmıyorum & 30 & 5,8 & 5,8 & 5.8 \\
\hline Katılmıyorum & 110 & 21,3 & 21,3 & 27,1 \\
\hline Orta düzeyde katılıyorum & 188 & 36,4 & 36,4 & 63,5 \\
\hline Kat1liyorum & 134 & 26,0 & 26,0 & 89,5 \\
\hline Kesinlikle katıliyorum & 52 & 10,1 & 10,1 & 100,0 \\
\hline Total & 516 & 100,0 & 100,0 & \\
\hline
\end{tabular}

Katılımcılar 'Artık insanlarla daha çok telefon ve internet üzerinden görüşeceğim' ifadesine \% 72,5 oranında kesinlikle katılıyorum, katılıyorum ve orta düzeyde katılıyorum yanıtlarını vermişlerdir. Buna karşılık kesinlikle katılmıyorum ve katılmıyorum seçenekleri ise $\% 27,1$ oranındadır.

Tablo 24. Covid-19 sürecinde internet ve sosyal medyada daha fazla vakit harcadım.

\begin{tabular}{|c|c|c|c|c|}
\hline & Frekans & Yüzde & Geçerli yüzde & Kümülatif yüzde \\
\hline Valid & 3 & ,6 & ,6 & ,6 \\
\hline Kesinlikle katılmıyorum & 13 & 2,5 & 2,5 & 2,5 \\
\hline Katılmiyorum & 50 & 9,7 & 9,7 & 12.2 \\
\hline Orta düzeyde katılıyorum & 87 & 16,9 & 16,9 & 29,1 \\
\hline Katıliyorum & 188 & 36,4 & 36,4 & 65,5 \\
\hline Kesinlikle katılıyorum & 175 & 33,9 & 33,9 & 100,0 \\
\hline Total & 516 & 100,0 & 100,0 & \\
\hline
\end{tabular}

Katılımcılar 'Covid-19 sürecinde internet ve sosyal medyada daha fazla vakit harcadım' ifadesine $\% 87,6$ oranında kesinlikle katılıyorum, katılıyorum ve orta düzeyde katılıyorum yanıtlarını vermişlerdir. Buna karşılık kesinlikle katılmıyorum ve katılmıyorum seçenekleri ise \%12,2 oranındadır. 
Tablo 25. Covid-19 sürecinde kendime yeni iş, uğraş ve hobiler edindim.

\begin{tabular}{|c|c|c|c|c|}
\hline & Frekans & Yüzde & Geçerli yüzde & Kümülatif yüzde \\
\hline Valid & 2 & $\overline{4}$ & $\overline{4}$ & $\overline{4}$ \\
\hline Kesinlikle katılmıyorum & 35 & 6,8 & 6,8 & 6,8 \\
\hline Katılmıyorum & 121 & 23,4 & 23,4 & 30,2 \\
\hline Orta düzeyde katılıyorum & 169 & 32,8 & 32,8 & 63,0 \\
\hline Katıliyorum & 134 & 26,0 & 26,0 & 89,0 \\
\hline Kesinlikle katıliyorum & 55 & 10,7 & 10,7 & 100,0 \\
\hline Total & 516 & 100,0 & 100,0 & \\
\hline
\end{tabular}

Katılımcılar 'Covid-19 sürecinde kendime yeni iş, uğraş ve hobiler edindim' ifadesine \%62,6 oranında kesinlikle katılıyorum, katılıyorum ve orta düzeyde katılıyorum yanıtlarını vermişlerdir. Buna karşılık kesinlikle katılmıyorum ve katılmıyorum seçenekleri ise \%37,0 oranındadır.

Tablo 26. İmkânım olsa şehirden ve apartman hayatından uzaklaşırdım.

\begin{tabular}{|c|c|c|c|c|}
\hline & Frekans & Yüzde & Geçerli yüzde & Kümülatif yüzde \\
\hline Valid & 2 &, 4 & ,4 &, 4 \\
\hline Kesinlikle katılmıyorum & 22 & 4,3 & 4,3 & 4,3 \\
\hline Katılmıyorum & 31 & 6,0 & 6,0 & 10,3 \\
\hline Orta düzeyde katıliyorum & 62 & 12,0 & 12,0 & 22,3 \\
\hline Katıliyorum & 142 & 27,5 & 27,5 & 49,8 \\
\hline Kesinlikle katıliyorum & 257 & 49,8 & 49,8 & 100,0 \\
\hline Total & 516 & 100,0 & 100,0 & \\
\hline
\end{tabular}

Katılımcılar 'İmkânım olsa şehirden ve apartman hayatından uzaklaşırdım' ifadesine \%89,3 oranında kesinlikle katılıyorum, katılıyorum ve orta düzeyde katılıyorum yanıtlarını vermişlerdir. Buna karşılık kesinlikle katılmıyorum ve katılmıyorum seçenekleri ise \%10,3 oranındadır.

\section{Sonuç ve Değerlendirme}

Covid-19 salgınıyla birlikte dünyanın büyük bir kısmı adeta zorunlu izolasyona tabi tutuldu. Bu süreçte bireysel ve toplumsal bazda pek çok olumsuzluklarla karşı karşıya kalındı. Psikolojik, sosyolojik ve ekonomik temelli ortaya çıkan bu olumsuzlukların etkilerini azaltabilmek maksadıyla ulusal ve uluslararası düzeyde büyük çaba sarf edilmiştir. Ancak pandeminin etkisi ülkeden ülkeye, toplumdan topluma farklılık göstermekle birlikte ülkelerin kendi içinde bazı özel tedbirler almasını ve kendine özgü bazı çalışmalar yapmasını gerekli kılmaktadır. Covid-19 salgınının Türk toplumsal yaşamı ve Türk kültürü üzerine etkilerin tespit etmek maksadıyla yapılan bu çalışma da koronavirüsün toplumumuz üzerindeki uzun vadede ortaya çıkarabileceği olumsuz etkilerin neler olabileceğinin belirlenmesine katk1 sağlamak maksadıyla hazırlanmıştır.

Çalışmada, katılımcılar 'Covid-19 hayata bakışımı tümüyle değiştirdi' ifadesine \%87,0 oranında kesinlikle katılıyorum, katılıyorum ve orta düzeyde katılıyorum yanıtlarını vermişlerdir. Yine katılımcılar 'Bundan sonra benim için hiçbir şey eskisi gibi olmayacak' ifadesine, \%72,2 oranında kesinlikle katılıyorum, katılıyorum ve orta düzeyde katılıyorum yanıtlarını vermişlerdir. Bu durum katılımcıların 
büyük çoğunluğunun pandemiyle birlikte insanları yeni bir yaşam tarzının beklediğini düşündükleri ve kendileri için artık 'hiçbir şeyin eskisi gibi olamayacağının' bilincinde olduklarının ortaya koymaktadır.

Katılımcıların yarısından fazlası $(\% 52,3)$ Covid-19'un arkadaşlık ilişkilerini olumsuz etkilediğini, yarısına yakını $(\% 45,0)$ ise bu süreçte akrabalık ilişkilerinin olumsuz etkilediğini beyan etmişlerdir. Bu durum salgının akrabalık ve arkadaşlık ilişkilerine önemli ölçüde zarar verdiğini göstermektedir. $\mathrm{Bu}$ bağlamda Katılımcıların 'Bundan sonra arkadaşlarımla daha az görüşeceğim' ifadesine \% 45,3 tamamen ya da kısmen katıldıkları, 'Bundan sonra akrabalarımla daha az görüşeceğim' ifadesine ise \%51,6 oranında tamamen ya da kısmen katılmaları bu ilişkilerin uzun vadede zarar görebileceğine işaret etmektedir.

Çalışmaya katılanların hemen hemen yarısı (\%48,3'ü) Covid-19 sürecinde tamamen ya da kısmen kendini çok yalnız hissettiklerini belirtmişlerdir. Katılımcıların \%65,7'si beslenme alışkanlıklarının, \%70,1'i de uyku-dinlenme alışkanlıklarının tamamen ya da kısmen değiştiğini beyan etmişlerdir. Bu durum geleneksel beslenme ve dinlenme alışkanlıklarının bu süreçte değişikliğe uğradığını ortaya koymaktadır.

Katılımcılar 'Artık insanlarla aramdaki sosyal mesafeye daha fazla dikkat edeceğim' ifadesine \%92,7 gibi büyük bir oranda kesinlikle katılıyorum, katılıyorum ve orta düzeyde katılıyorum yanıtlarını vermişlerdir. Yine 'Sosyal mesafe kuralının bende alışkanlığa dönüşeceğini düşünüyorum' ifadesine \%80,8 gibi bir oranda da kesinlikle katılıyorum, katılıyorum ve orta düzeyde katılıyorum yanıtlarını vermişlerdir. Çalışmaya katılanların 'Bundan sonra mecbur kalmazsam kimseyle tokalaşmayı düşünmüyorum' ifadesine \%71,1 oranında kesinlikle kat1liyorum, katılıyorum ve orta düzeyde kat1liyorum yanitını, 'Bundan sonra kolay kolay kimseyle sarılmayı düşünmüyorum' ifadesine \% $\%$, 0 oranında kesinlikle katılıyorum, katılıyorum ve orta düzeyde katılıyorum yanıtını vermişlerdir. $\mathrm{Bu}$ veriler de bize açıkça gösteriyor ki, Türk kültüründe önemli bir yere sahip olan tokalaşma, sarılma, yakın durma gibi kültürel unsurlar giderek unutulmaya başlanacaktır.

Katılımcılar 'Covid-19 sürecinde teknolojik cihaz (telefon, bilgisayar vb.) kullanımım arttı' ifadesine \%91,3 gibi çok yüksek bir oranda kesinlikle katılıyorum, katılıyorum ve orta düzeyde katılıyorum yanıtlarını vermişlerdir. Katılımcılar 'Artık insanlarla daha çok telefon ve internet üzerinden görüşeceğim' ifadesine \% 72,5 oranında kesinlikle katılıyorum, katılıyorum ve orta düzeyde katılıyorum yanıtını, 'Covid-19 sürecinde internet ve sosyal medyada daha fazla vakit harcadım' ifadesine \%87,6 gibi yine oldukça yükse bir oranda kesinlikle katılıyorum, katılıyorum ve orta düzeyde katılıyorum yanıtlarını vermişlerdir. $\mathrm{Bu}$ sonuçlar da bize teknolojiye bağımlılığın ve teknolojik cihaz kullanımının toplumda giderek arttığını ve ilişkilerin internet ortamına taşınıyor olduğunu göstermektedir.

Covid-19 salgını sürecinde yapılan "evde kal” çağrıları bireylerin sosyal hayatlarını olumsuz yönde etkileyerek evlerde uzun vakit geçirmelerine neden olmuş ve bireyler bu yeni duruma alışmaya çalışırken kültürel yapılarının değiştiğini çalışma içerisinde yapılan araştırma verileri göstermektedir. Toplumun bu yeni düzene ayak uydurması sürecinde yaşanabilecek kültürel değişimlerin "sağlıklı" bir yolla olmasından dolayı bir sorun teşkil etmemektedir. Öyle ki 'Kolonya, dezenfektan, el yıkama vb. benim için artık vazgeçilmez oldu' seçeneğine katılımcıların \%86,3'ünün olumlu yanıt vermesi bunu ispatlamaktadır. Fakat tokalaşma ve sarılmanın olmaması, toplum içinde uygulanan sosyal mesafe gibi insanları birbirinden uzaklaştıran kültürün içerisinde yer alan sıcakkanlılığın bir göstergesidir. Bu gibi insan etkileşimlerinin kültürde kalıcı hale gelebilmesi kültürden kültüre değişiklik göstermekle birlikte olumsuz bir değişikliğe de neden olabilmektedir.

Araştırma verileri 1şığında Covid-19 salgınının uzun vadede Türk kültürü ve Türk toplumsal yaşamı üzerinde bazı farklılaşmalara sebep olabileceği değerlendirilmektedir. Çalışmanın, salgın hastalıkların toplumsal yapı üzerinde bırakabilecekleri etkilerin neler olabileceğinin değerlendirilmesi açısından alanda önemli katkılar sağlayacağı düşünülmektedir. 


\section{Kaynakça}

Açıkgöz, Ö, Günay, A. (2020). The early impact of the Covid-19 pandemic on the global and Turkish economy. Turkish Journal of Medical Sciences, 50 (), 520-526. Retrieved from https://dergipark.org.tr/tr/pub/tbtkmedical/issue/53865/724507

Boseley, S. (2020). Coronavirus 'could infect $60 \%$ of global population if unchecked'. https://www. theguardian.com/world/2020/feb/11/coronavirus-expert-warns-infection-couldreach-60-of-worldspopulation (erişim: 01.04.2020).

Bolsoy N, Sevil Ü. (2010). Sağlık-Hastalık ve Kültür Etkileşimi. Anadolu Hemşirelik ve Sağllk Bilimleri Dergisi. 9 (3), 78-87.

Bulut, S. (Ed.) (2020) Kültürlerarası İletişim, Erzurum: Atatürk Üniversitesi Açıköğretim Fakültesi Yayınlar1

Congar, K. (2020). Koronavirüs: Modern tarihin en kapsamlı yasaklarını Avrupa'da hangi ülkeler uyguluyor? https://tr.euronews.com/2020/03/21/avrupa-da-hangi-ulkeler-koronavirussebebiylekarantina-ve-sokaga-cikma-yasagi-uyguluyor (Erişim: 01.04.2020).

Edles, L. D. (2006). 'Uygulamalı Kültürel Sosyoloji', İstanbul: Babil Yayınları. s.6

Escarus (2020). Bir Eko-Sosyal Kriz Olarak Covid-19 Salgını ve Sürdürülebilirlik Raporu, Türkiye Sinai Kalkınma Bankası Sürdürülebilirlik Danışmanlığı A.Ş., 20 Mayıs 2020. s.37

Göka, E. (2012) Su ile Mahrem Maceramız. Türk Yurdu Ağustos 2012, Y11 101- Sayı 300.

Gümüş, M. (2011). Türk Ailesi ve Modernleşme. Istanbul Journal of Sociological Studies , 0 (24), Retrieved from https://dergipark.org.tr/tr/pub/iusoskon/issue/9526/119054

Keskin, A. (2017). Türk Kültüründe "Selamlaşma" ve "Vedalaşma” Hakkında Genel Bir Değerlendirme. Türk Dünyası Dil ve Edebiyat Dergisi, (43), 125-146. Retrieved from https://dergipark.org.tr/tr/pub/tdded/ issue/38105/409628

Kroeber, A. L. \& Kluckhohn, C. (1952). Culture: A critical review of comcepts and definitions. Cambridge, MA: Peabody Museum, 47 (1).

Mahiroğulları, A. (2010). Küreselleşmenin Kültürel Değerler Üzerine Etkisi, Journal of Social Policy Conferences , 0 (50) , 1275-1288

Öğ̈̈t-Eker, G. (2001). Yazılı Kaynaklarda Türk Ailesi. Erdem, 13 (37), 131-158. Retrieved from https://dergipark.org.tr/tr/pub/erdem/issue/44288/546823

Reeves, M., vd. (2020) "Sensing and Shaping the Post-COVID Era", BCG Henderson Institute, 03.04.2020

Smıth, P. (2007). 'Kültürel Kuram', İstanbul: Babil Yayınları. s.13

Toğrol, B. (2012). Kültür Taşıyıcı Olarak Türk Ailesi: Doğu'dan ve Batı'dan Örnekler. Psikoloji Çalışmalarl, 19 (0) , 51-58 . Retrieved from https://dergipark.org.tr/tr/pub/iupcd/issue /9414/118006

Tüba (2020). “Covid-19 Pandemi Değerlendirme Raporu”, Türkiye Bilimler Akademisi Yayınları, TÜBA Raporları No: 34, Nisan 2020

Tyap (2020) "Covıd-19 Salgınının Sosyolojik Analizi- 1", (Ed., Lütfi Sunar) Toplumsal Yapı Araştırmaları Programı, Nisan. 2020

Ünalan, D. (2018) İletişim Biçemleri ve Kültürlerarası Duyarlılık Geliştirme Süreçlerinin "PK” Filmi Özelinde İncelenmesi, Turkish Online Journal of Design, Art and Communication- TOJDAC, ISSN: 2146-5193, April 2018 Volume 8 Issue 2, p. 437-446 
Williams, R., (1993) 'Kültür', İstanbul: İmge Yayınları.

Yavuz, K. (2020). Covid-19 Salgınının Sosyal Politikanın Geleceği Üzerine Etkileri, Akademik Sosyal Araştırmalar Dergisi, Yı1: 7, Say1: 45, Nisan 2020, s. 181-193, ISSN: 2149-0821 Doi Number: http://dx. vdoi.org/10.29228/SOBIDER.42843

BM Ekonomik, Sosyal ve Kültürel Haklar Komitesi Bildirisi, Kabul Tarihi: 6 Nisan 2020

\section{İnternet Kaynakları}

Covid-19 Coronavirus Pandemic, https://www.worldometers.info/coronavirus/ (Erişim Tarihi: 13.07.2020)

Küreselleşme ve Kültürlerarası İletişim (b.t.) Murat Yayınları, https://muratyayinlari.com/storage/ catalogs/ 0558372001520059833.pdf (Erişim Tarihi: 20.06.2020)

Göka, E. (2012) Su ile Mahrem Mecramız. https://www.turkyurdu.com.tr/yazar-yazi.php?id=1326

Özcan, Şefik (2014). Toplumsal Katılım, Politik İçerme ve Dışlama Söylemleri Bağlamında Kültürün Tanımlanması ve Çağdaş Sanat, https://www.e-skop.com/skopbulten/toplumsal-katilim-politikicerme-ve-dislama-soylemleri-baglaminda-kulturun-tanimlanmasi-ve-cagdas-sanat/1835, (Erişim Tarihi: 20.06.2020). 